\title{
Hedonism as a Decision Factor and Technologic Usage
}

\author{
Hedonismo como um Fator de Decisão e Uso Tecnológico
}

Hedonismo como un Factor de Decisión y Uso Tecnológico

\section{Emílio José Montero Arruda Filho Ruby Roy Dholakia ${ }^{2}$}

Received on August 17, 2012 / Approved on September 3, 2013

Responsible Editor: João Maurício Gama Boaventura, Dr.

Evaluation Process: Double Blind Review

\begin{abstract}
In the current selection and use of technological products, consumers prefer to adopt products which include new service packages and features. This article presents that all-in-one or integrated products are hedonic but explanation for use thereof is utilitarian. This paper analyzes factors of technological integration, hedonic and utilitarian behavior, in addition to the more traditional environmental factors of price, budget, brand, and choice. All variables presented can be considered decision factors or factors that change preference, given the inclusion of several integrations. Accordingly, we assessed smart phones with different services integrated, such as Internet, wireless, music, video, and camera functions. Our findings support our assertion that consumer preference is based on the integration of product features for both enjoyment and pleasure of use.
\end{abstract}

Keywords: Hedonism. Utilitarianism. Technological preference. System integration.

\section{RESUMO}

O uso de produtos tecnológicos na atualidade demonstra que consumidores preferem adotar novas tecnologias aliadas a pacotes de novos serviços incluídos nos produtos. Este artigo apresenta que produtos com multifuncionalidades ou integraçôes são hedônicos e possuem justificação de seu uso como se fossem utilitários, apresentando fatores de integração tecnológica, comportamento hedônico e utilitário, além de ambientes criados pelo preço, orçamento, marca e escolha, que seria o fato de comprarem o produto para si mesmos ou receberem-no como um presente. Todas as variáveis apresentadas servem como fatores de decisão ou mudanças de preferência, dada a composição de múltiplas integraçôes. Com isso, avaliam-se neste trabalho os dispositivos celulares conhecidos como smartphones, com diferentes serviços integrados, como internet, wireless, música, câmera fotográfica e câmera de vídeo, apresentando que mesmo quando esses produtos possuem maior qualidade, como produtos

1. Doctor in Marketing from Università Degli Studi Di Bergamo, Italy. Professor at University of Amazonia (Unama). [emilio.arruda@unama.br]

Author's address: Av. Alcindo Cacela, 287, 4º andar, Bloco E, Belém-PA. CEP 66060-902, Brasil

2. Doctor in Marketing from Northwestern University, United States. Professor da University of Rhode Island. [ruby@uri.edu] Author's address: 7 Lippitt Road, Kingston - RI. Zip Code: 02881, USA. 
individuais, a preferência ainda é encorajada para equipamentos possuindo todas essas integrações em um só equipamento, baseado na diversão e prazer de uso.

Palavras-chave: Hedonismo. Utilitarismo. Preferência tecnológica. Integração de sistemas.

\section{RESUMEN}

El uso de productos tecnológicos en la actualidad demuestra que los consumidores prefieren adoptar nuevas tecnologías aliadas a paquetes de nuevos servicios incluidos en los productos. Este artículo presenta que los productos con multifuncionalidades o integraciones son hedónicos y poseen justificación de su uso como se fuesen utilitarios, presentando factores de integración tecnológica, comportamiento hedónico y utilitario, además de ambientes creados por el precio, presupuesto, marca y la elección, que consiste en el hecho de comprar el producto para si mismo o adquirirlo como regalo. Todas esas variables presentadas sirven como factores de decisión o cambios de preferencia, debido a la composición de diversas integraciones. Con ello, se evalúan en este trabajo los dispositivos celulares conocidos como smartphones, con diferentes servicios integrados como internet, wi-fi, música, cámara fotográfica y cámara de video, sosteniendo que incluso cuando estos productos poseen mayor cualidad, como productos individuales, la preferencia aún es valorada para equipos que poseen todas estas integraciones en un sólo equipo basado en la diversión y placer de uso.

Palabras clave: Hedonismo. Utilitarismo. Preferencia tecnológica. Integración de sistemas.

\section{INTRODUCTION}

The diversified development in the telecommunications market is currently reflected on the mobile communication devices. Among these, the mobile phone has been regularly modified, through system integration and technological convergence (KIM, LEE, KOH, 2005; TAYLOR, TITMUSS, LEBRE, 1999; VRDOLJAK, VRDOLJAK, SKUGOR, 2000) as tools, therefore connecting all service possibilities into a single product. These devices, known as "all in one" (NUNES, WILSON, KAMBIL, 2000), enable consumers not only to communicate through voice, text or video, but also to listen to music, manage their work schedule, assess market stocks, have access to political and social news, their email and the Internet. Therefore, one can observe that all these services have been working properly, not for the use of a differentiated market technique or specific marketing tool, but for the use of psychology on consumption in our current market only (BRUNNER, 1996), based on consumers' needs and desires.

As a result, these devices have evolved not to be a simple utilitarian product, which is the purpose for which they were created. The market has been offering them more generically, with reduced utilitarian factors and increased hedonic factors, having users decide to use them as tools for fun and pleasure. According to Katz and Sugiyama (2006), people use mobile technologies as tools in their daily lives as an extension of their bodies. This leads to interesting questions regarding the value created by consumers, given the hedonic and utilitarian benefits of these devices, and the conditions under which these values are developed from a social point of view.

\section{CONVERGENCE ARTICULATED WITH THE USE}

Products have changed with technological convergence, offering all accesses to different communication services in one direction, and system integration, offering a product with all tools in one place. Smart phones (JOKELA, 2004) were launched with video-cameras using the mp 4 format, mp3 for music, Internet access, access to emails and download of programs and 
services simultaneously. Digital cameras, which are more and more powerful, were integrated and are constantly updated in mobile devices, just as video-cameras are. Good-quality interactive games, based on Java (FUNK, 2004), have been used as well. Access to payments and private networks, also using the Java program, wireless connectivity and other programs interacting with users have been created in these devices, which leads to greater mobility for m-commerce (electronic commerce that allows purchases and payments through mobile phones), and shows us why these are so commonly called all-in-one in the USA.

The great business move in the converging market was not the creation of different services in a single system or device, but putting many of these services together (KIM, LEE, KOH, 2005), which leads to a confusion of the consumers' experience, given their actual knowledge of the product (HOCH, 2002), and lack of skills to explore the benefits of available convergence in these pieces of equipment. That a single product has a number of uses increased difficulty of a previous conception of using each service separately or jointly (NUNES, 2000). Accordingly, it is virtually impossible for a consumer to clearly and appropriately foresee how they will use the device, given the cost-effectiveness thereof, before buying a new model with new integrations.

\section{CONCEPTUAL FRAMEWORK}

This article quantifies the technological preference of consumers, addresses the use of these products, and shows that this equipment is mostly used or acquired for fun, pleasure or social presence (OKADA, 2005; KATZ, SUGIYAMA, 2006). Even if the product is highly utilitarian, such as a mobile phone, we observed that it has lost its utilitarianism properties, which are now secondary factors. Therefore, we analyze that consumers have used these devices for a number of purposes for which they were not created.
Some research is presented on scenarios for choice, showing consumers who prefer technologies that offer more possibilities to those offering few features (HARRIS, BLAIR, 2006), even if the complexity of the assessment process is increased. Integrated products (products with different technical benefits and integrated in a single device) are preferred even among those consumers who already have these benefits in separate devices. This is because these integrated products have service diversity features, considering the fun they can provide (NOWLIS, MANDEL, McCABE, 2004). For as plausible as it might sound, given the increased benefits, such as convenience, portability and mobility, among others, quality support and price are not the same for integrated and dedicated products (HAN, CHUNG, SOHN, 2009).

As an example, we suggest smart phone consumers who look for these devices with digital camera, Internet, music and other similar integrated features, even when they already have products with separate devices. The explanation is clear and defined by them as a utilitarian factor, in which a number of consumers are focusing upon having an all-in-one, thus integrating all services. They explain that, with this all-in-one, they can go out without having to carry three or four different pieces of equipment, which results in mobility.

When these integrated products are created, it is virtually impossible to insert service quality in a 2.5-inch screen mobile phone and compare it to a 50-inch screen TV set (SNOJ, KORDA, MUMEL, 2004). The quality of photos taken with a phone and with digital cameras, both of good brands and with the same number of megapixel - which, according to the market, defines the quality of a picture -, is not the same, as lenses of a device designed specifically to perform a service and of another one which has this service as an integration (to add value to the product) are not to be compared. This is also true when it comes to typing a message in a computer keyboard and a small mobile phone keyboard, which cannot be compared either. Then, why have these services, applications and integrations been created in a mobile phone? 
Under a technical perspective, the mobility factor lies in this integration, which was developed through generation of new market opportunities. Accordingly, these new smart phones have been developed to provide new options for events in which, even without a digital camera, when someone is walking down a street, they can take pictures of an unexpected or unplanned event using their mobile phones. This may not be the best picture of their lives or professional material, but may be something unexpected to which the user has had access.

Other possibilities are evidenced by common expressions, such as users waiting for a bus or a plane, or commuting to work, with the possibility of listening to music from their mobile phones, checking whether the game on TV started, what the score is or even what happened at that exact moment in their city by checking the news. In this context of technology use, the difference is that the current MP3 player is more powerful for music that a mobile phone, the consumer has a better TV set at home to watch games and the news, and each type of dedicated product was created with the specific quality for that service.

As the quality and capacity levels cannot be compared (NEELAMEGHAM, CHINTAGUNTA, 2004), the hierarchical relationship between features of an integrated device and a dedicated device is different according to the circumstances. Therefore, integrated features in a mobile phone are considered supplements and not primary values; in order to ensure the same quality level in features of a mobile phone, the price thereof would have to be increased to an almost unaffordable price. Another important issue is that the device is an allin-one piece of technology; therefore, when it is lost or it breaks down, all products are lost at once. Accordingly, we observe that the strength factor is not considered by the integrated equipment consumer as well, and the perception of risk with the purchase of products can be seen as an issue not considered.
Given this perspective, why should one have a recently launched mobile phone with integrated 10-megapixel camera if the price difference is so great and the customer has a dedicated piece of equipment, with higher quality, to do the same thing? The consumer focuses upon two factors at this moment: first, regarding the need for more recent equipment - latest model in the market; second, regarding the need for these features in a devices so as to have fun, play and refer to a social attitude - social value, to be seen using something modern, that brings status to themselves or is in fashion.

\section{I Studies of technology-related behavioral factors}

Based on the integrations and number of services in the abovementioned technological equipment, plus the explanation for use, other factors are supplementary in explaining the different decisions in this specific technological consumption. Expensive devices are chosen by consumers with fun behaviors - hedonic behavior, in which the consumer's choice is controlled by a hedonic value, but explained in terms of utilitarian values (OKADA, 2005). Therefore, this leads the study to significant differences in use behavior.

Another study on the context shows that, in choosing different brands and prices, preference for low-cost brands is based on an explanation importance different than that for a brand that is similarly considered as far as technology is concerned, but at a higher price (BRUCKS, ZEITHALM, NAYLOR, 2000). That is, brand reputation must follow logically changes in prices.

This is also true when a budget is defined to buy a new product or an update. Two behaviors are noticed in this process: (1) hedonic consumers are more focused on multiple needs, meeting their budget needs (HEATH, SOLL, 1996), and (2) utilitarian consumers limit their purchases, based on product category and on their perception of quality and warranty (COWLEY, MITCHELL, 2003). 
Hedonic consumers choose their equipment based on the possibility of receiving them as a gift, low-price purchases, payment promotions, or when the same group of consumers has this equipment (LIU, 2002). Utilitarian consumers choose their equipment based on service quality, coverage area and items that ensure communication quality (BRUCKS, ZEITHALM, NAYLOR, 2000).

The difference between hedonic and utilitarian is presented in this article, based on use factors and types of consumption - nowadays, consumers are upgrading their mobile phones more frequently than necessary, changing their phones and other technological equipment (DANAHER, HARDIE, PUTSIS JUNIOR, 2001) only to be more up-to-date and have the latest model launched in the market. Other consumers wait longer to own new equipment, but always look for the latest model, and choose it considering status social values.

\subsection{Study development}

A number of empirical studies were conducted to classify issues created in the consumer choice literature, but nothing specifically focused on choices of technological products only. As telecommunications products have significantly evolved over time, from strictly utilitarian equipment to a mix of hedonic integration in our days, this research focused upon investigating how consumers choose and explain their choices, and how preferences affect current use behaviors.

Based on Okada's (2005) theory, whereby consumers feel guilty when their preferences are based on hedonic values, and therefore need to explain their decision and, as confirmed by Katz and Sugiyama (2006), for whom mobile devices have become personal and social identity, hypotheses are created with respect to:

H1: The higher the integration level in a product, the higher its hedonism level is valued, and, as a result, its utilitarianism level, as a way to explain the acquisition.
According to Harris and Blair (2006), consumers feel safer with integrated products than with dedicated products, with a lower risk perception regarding equipment that provides multiple benefits. Given the integration of multiple benefits, however, consumers believe it is more difficult to estimate their use behavior in the past, as they cannot compare a specific benefit from a multiple extraction (NUNES, 2000). They are not adept at recognizing the diagnosticity of their consumption experience, and confuse familiarity with and knowledge of the product $(\mathrm{HOCH}, 2002)$. As a result, consumers tend to overestimate the use, and are willing to pay a high price therefore.

H2: Even with little experience in using the current product, consumers expect they will use more than one new product when it has a number of integrations.

Heath and Soll (1996) say that, when a certain expense is related multiple categories, people tend to adopt hedonic positions that meet their short-term interest needs. Danaher, Hardie and Putsis Junior (2001) say that consumers look for updates even though they do not have the previous version for the launched technology. Brucks, Zeithalm and Naylor (2000) describe the use of brand $v s$. price as an indicator of quality, showing the interconnection and relation of variables focused on perceiving this quality. They then propose that:

H3: When the brand is considered top, the product chosen is hedonic, as the explanation is the quality involved in the value (name) of the brand, even if the product price is high.

We analyze that alternatives of brand quality and price should favor reactions with product popularity (SIMONSON, NOWLIS, LEMON, 1993). Liu (2002) shows promotional effect characteristics on brand decision as a preference factor. Thus: 
H4: When the price is considered low, consumers do not need to explain their choices, electing hedonic products with no importance of the brand involved.

Accordingly, we detect that low prices require no explanation, as the feeling of guilt is not present in purchases that are not perceived as money waste. That is, no risk perception is involved (DAHL, HONEA, MANCHANDA, 2005).

Thus, continuing this study related to the consumption behavior and analyzing the change in preference given the change in choice environment, a certain amount is established to set a budget for the acquisition of a new product, as we know that including new attributes increases sales development when consumers interpret those attributes as benefits (MUKHERJEE, HOYER, 2001). Hock (2002) presents consumer's commitment in confirming arguments, setting out attractive features shared, which provides additional support to initial choice, and proposes:

H5: Consumers are willing to spend more than their budget if the integrated product offers hedonic value in terms of adjunct features.

According to Okada's (2005) studies, guilt and explanation are interconnected concepts, not theories, competing for explanations of choosing utilitarian products over hedonic products. Then this is proposed:

H6: The hedonic value is higher when the product is received as a gift than when it is bought by the consumer as little guilt is related to gifts.

Accordingly, we conclude our proposal for reference analysis of consumer preferences, from a service integration perspective - multifunctionality, hedonic values and utilitarian values, as proposed by hypotheses 1 and 2 . Change in choice decision was measured by both differentiated environments created - scenarios, to demonstrate that, considering a certain context imposed to the consumer, their choosing the same technological product may change significantly and with differentiated perceptions according to values described in hypotheses 3, 4, 5 and 6 .

\subsection{Primary study of technological reference, acceptance and knowledge of the product - Study 1}

\subsection{Method for Study 1}

\subsection{I.I Research design}

The first study intends to reference the perception, value and preference of consumption based on hedonic and utilitarian attributes of technological products, as these are different in levels of desire and need by users, based on the inclusion of multiple technologies and usability culture. Therefore, in order to conduct this study, university students were randomly recruited from general undergraduate fields. They received extra points (supplementary activities) for participating in the research and responding a questionnaire.

The study was conducted to individually measure hedonism, utilitarianism and use of products represented as dedicated and/or integrated equipment, for the different levels of mobile phones proposed. This scenario was applied to 70 students in the Engineering College in the North of Brazil.

\subsection{I.2 Stimulus}

Nine different products were analyzed. These devices had from simple features to integrated attributes with multiple functionalities - a basic mobile phone, for example, with capacity to make calls and memory for names and numbers, a 10-megapixel digital camera, an mp3 device, a PDA, a mobile phone with $\mathrm{mp} 3$, a digital camera with integrated mp3, a mobile phone with a digital camera, a mobile phone with PDA and a mobile phone with integrated $\mathrm{mp} 3$, digital camera and PDA. Each respondent was given the same type of questionnaire with these products in order to assess usability and knowledge (past experience) of each thereof, in addition to hedonic 
and utilitarian values and value perception, among others. Pictures and descriptions of each product were produced before each question in order to increase potential previous knowledge of the product or understanding of how each thereof works separately. This may lead to the respondents' better ability to answer their intention to use or buy the product given their understanding or knowledge of this type of equipment.

\subsection{I.3 Independent variables}

Hedonism, utilitarianism and risk perception were used as independent variables for the nine products mentioned above. Based on different questions measuring the same construct, a reliability analysis was conducted to aggregate two or more factors (questions) in a single factor, or to analyze which questions could be dropped. "Fun", "pleasure" and "satisfaction" were used as measurements to define hedonism; "valued" and "need" were used to define utilitarianism, and "risky" or "problematic" were measuring the level of risk perception to buy or own this product. The scales were obtained from studies conducted by Okada (2005), who represents that variables measure each construct presented.

\subsection{I.4 Dependent variables}

"Social" and "available to pay" factors were used as dependent variables. "Social" was defined by combining the question about prosperity with the mobile phone and the happiness it brought to the respondent, whereas "availability to pay" was in the value presented by respondent and in their intention to modify or increase this payment, whenever they perceived value added to the product.

All questions were measured using the Linkert scale level, from 1 to 7 , for each individual item, in connection with the abovementioned arguments. The assessment of use (knowledge) was determined by analyzing their past experience and the use of each feature, based on mobile phones each consumer (respondent) held at the time of the assessment, as well as their expectations for the scenarios presented. We checked whether all features were necessary and highly used, which should determine the individual and the joint use for a converging product.

\subsection{I.5 Procedure}

The questionnaire applied was prepared by measuring fun, pleasure, satisfaction, need, value to own, prosperity, happiness, risk to buy, problematic to acquire and availability to pay - in two phases of willingness, in addition to some demographic questions and knowledge assessment in connection with respondents' past experience with these products and their use. The questionnaire database was worked on the SPSS software, in order to assess the reliability analysis to reduce less significant results and increase highly significant results assessed in the components measured. After this database reorganization with new factors generated, a regression analysis was performed to the hypothetical theory proposed.

\subsubsection{Study 1 results}

Initially, averages were calculated for each factor proposed in the procedure. Figure 1 presents the hedonism by utilitarianism matrix, positioning the individual products used. Amounts in the reliability analysis performed for all constructs, defining the possibility to create new factors or leave them separate, were not produced for they contain a high number of analyses, as each one of the nine products had analyses for all constructs. The ideal number ranging from 0.7 to 0.9 was used to create new constructs, based on the arithmetic mean of the factors involved. We detected that virtually all utilitarian, hedonic, risk perception, social value and availability to pay values have been defined by total individual factors mentioned above. 


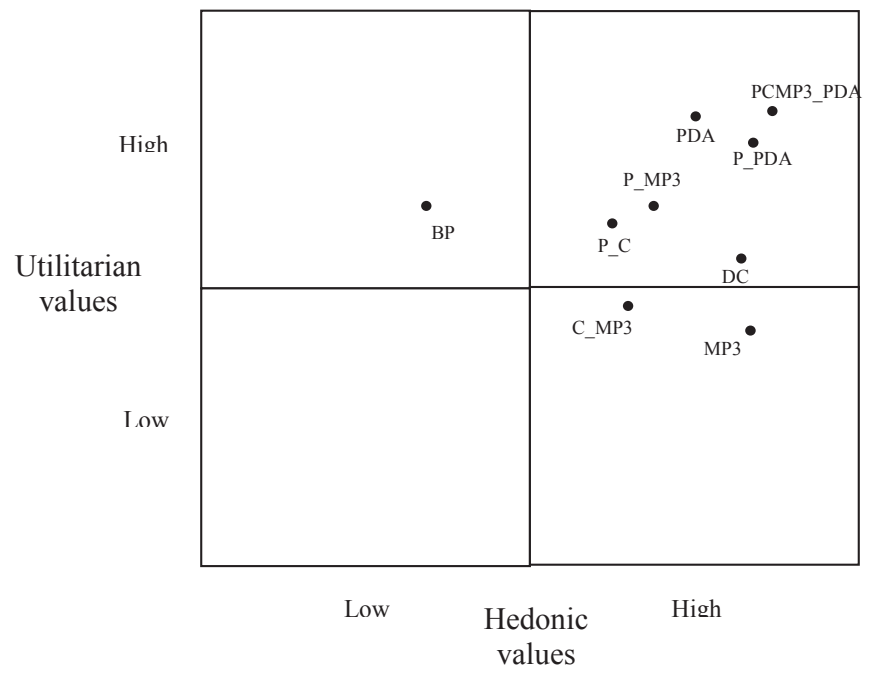

Representation in Figure 1: BP - Basic mobile phone, DC - Digital camera, MP3 - MP3 player, PDA - Personal Digital Assistant, P_C - phone with digital camera, P_mp3 - phone with mp3 player, C_mp3 - Digital camera with mp3 player, P_PDA - phone with PDA, PCMP3_PDA - phone with camera, mp3 and PDA.

FIGURE 1 - Matrix of utilitarianism and hedonism averages developed for each dedicated and integrated product.

Source: The authors.

According to the analysis conducted, only the "need" and "valued" factors of the digital camera were not added, based on their low cronbach alpha value, and were therefore presented individually in the regression. Other values, even those a bit lower than 0.7 - but very close by $5 \%$ -, were accepted because they were in the limit of the analysis, and considered as marginal reliability.

The regression analysis conducted, using social as a dependent variable and the hedonic and utilitarian factors as independent variables, resulted in good significance amounts for all products assessed. In some products, the risk factor - risk perception with purchase was positively relevant, which indicates that consumers are positively aware of this risk, with their intrinsic preferences and happiness related to the product. With relatively high $\mathrm{R}^{2}$ of 0.528 , the basic mobile phone was significant for the hedonism and utilitarianism, as seen in Table 1.

For $\mathrm{R}^{2}$ equal to 0.601 and 0.776 , respectively, for the phone with $\mathrm{PDA}$ and phone with all individual features together, the corresponding regressions developed are presented in Tables 2 and 3. We observed that dedicated products, such as the basic mobile phone, mp3 and digital camera, had no significance in risk perception, in Table 1, but when hedonic and multiple function features are integrated in the mobile phone, i.e., the product analyzed is a phone with $\mathrm{mp} 3$, camera or both, the risk perception increases and is perceived even for this factor.

TABLE 1 - Regression for basic mobile phone, assessing the social behavior with utilitarian and hedonic behaviors.

\begin{tabular}{lcccccc}
\hline \multirow{2}{*}{ Model (factors) } & \multicolumn{2}{c}{ Non-standard ratios } & Standard ratios & \multirow{2}{*}{ t } & Sig. (P) \\
\cline { 2 - 3 } & $\mathbf{B}$ & Standard error & Beta & & .173 & .863 \\
Constant & .078 & .450 & .091 & .482 & 5.362 & .000 \\
Utilitarian factor (basic phone) & .487 & .359 & .359 & 3.864 & .000 \\
Hedonic factor (basic phone) & .321 & .077 & .148 & 1.606 & .113 \\
Risk factor (basic phone) & .123 & & & & & \\
\hline
\end{tabular}

Dependent variable: social factor of basic phone.

Source: The authors. 
TABLE 2 - Regression for phone with PDA, assessing the social behavior with risk perception and utilitarian and hedonic behaviors.

\begin{tabular}{lccccc}
\hline Model (factors) & \multicolumn{2}{c}{ Non-standard ratios } & Standard ratios & t & Sig. (P) \\
\hline Constant & B & Standard error & Beta & & \\
Utilitarian factor (phone + PDA) & -0.223 & .615 & & -0.363 & .718 \\
Hedonic factor (phone + PDA) & .524 & .106 & .489 & 4.954 & .000 \\
Risk factor (phone + PDA) & .356 & .111 & .315 & .3 .199 & .002 \\
\hline
\end{tabular}

Source: The authors.

TABLE 3 - Regression for phone with all integrated features, assessing the social behavior with risk perception and utilitarian and hedonic behaviors.

\begin{tabular}{|c|c|c|c|c|c|}
\hline \multirow{2}{*}{ Model (factors) } & \multicolumn{2}{|c|}{ Non-standard ratios } & \multirow{2}{*}{$\begin{array}{c}\text { Standard ratios } \\
\text { Beta }\end{array}$} & \multirow{2}{*}{$\mathbf{t}$} & \multirow{2}{*}{ Sig. (P) } \\
\hline & B & Standard error & & & \\
\hline Constant & -1.819 & .528 & & -3.448 & .001 \\
\hline Utilitarian factor (phone + TS) & .421 & .117 & .342 & 3.607 & .001 \\
\hline Hedonic factor (phone + TS) & .751 & .124 & .571 & 6.058 & .000 \\
\hline Risk factor (phone + TS) & .070 & .037 & .115 & 1.915 & .060 \\
\hline & $\begin{array}{l}\text { social } f \\
\text { lucts int }\end{array}$ & $\begin{array}{l}\text { phone + camera } \\
\text { (Camera, mp3 ar }\end{array}$ & $\begin{array}{l}\text { np3 + PDA. } \\
\text { PDA) }\end{array}$ & & \\
\hline
\end{tabular}

Source: The authors.

Based on Figure 2, regressions for the "available to pay" factor as a dependent variable and social behavior as independent variable were performed for phone with PDA and phone with all features integrated. This resulted in significances stated in Tables 4 and 5, respectively.

Good results were found for all dedicated products, supporting the theory presented and the model designed in Figure 2. No significance was found between previous knowledge (use) and behavior factors, values and preferences.
The average of values analyzed for the valued factor increased from 4.12 to 6.16 , based on the new features integrated in the mobile phone, which confirms preference for integrated products. Figure 1 presented the average of explanation for each product assessed, reporting that the product with hedonic features is explained as utilitarian, even when they are clearly hedonic. This particular hedonism acceptance, which explains that the product is also utilitarian, moderately supports hypothesis 1 . 


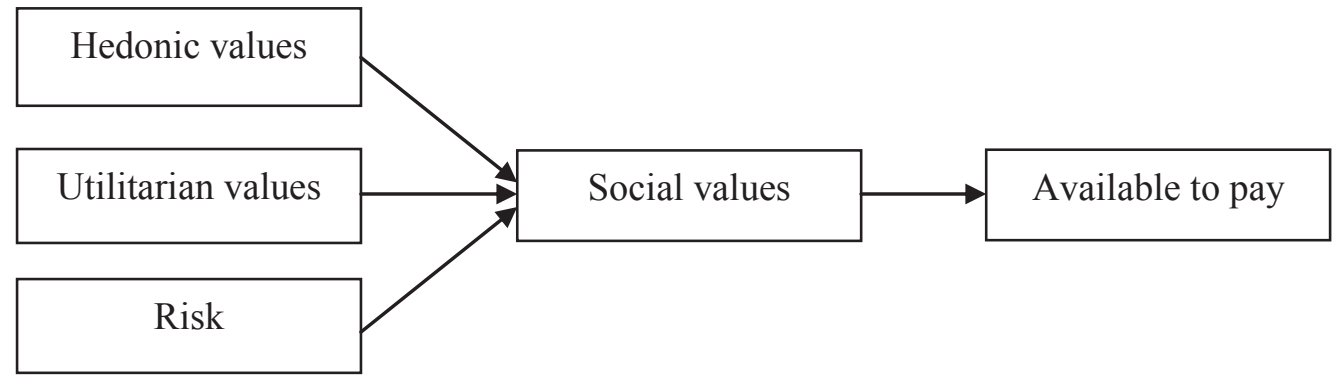

FIGURE 2 - Benchmarking Model designed for technological products

Source: The authors.

Of the 1 to 7 scale used, the use of each dedicated product and each integrated product was measured and resulted in averages 5.37, 3.31, $3.21,3.48,3.66,1.52,1.93,2.01$ and 4.04 for the mobile phone, $\mathrm{mp} 3$ player, $\mathrm{mp} 3$ in the phone, digital camera, camera in the phone, PDA, PDA in the phone, schedule and schedule in the phone, respectively. As these averages are low, previous knowledge and experience with these products and their uses are low, which supports our hypothesis 2, wherein consumers expect they will use another product with a number of integrations. The low average of current use and the high expectation of hedonism and utilitarianism in products mean that products are expected to be used, as consumers describe they do not use their current product much, i.e., they have no previous experience sufficient to define the use factors of this equipment - defining as very utilitarian or a lot of fun, meaning, based on the average values above for the behavior items, that the expectation is clear for the equipment analyzed.

TABLE 4 - Regression for phone with PDA, assessing for the available to pay factor with social behavior.

\begin{tabular}{|c|c|c|c|c|c|}
\hline \multirow{2}{*}{ Model (factors) } & \multicolumn{2}{|c|}{ Non-standard ratios } & \multirow{2}{*}{$\begin{array}{c}\text { Standard ratios } \\
\text { Beta }\end{array}$} & \multirow{2}{*}{$\mathbf{t}$} & \multirow{2}{*}{ Sig. (P) } \\
\hline & B & Standard error & & & \\
\hline Constant & 208.928 & 382.344 & & .546 & .587 \\
\hline Social factor (phone + PDA) & 143.581 & 67.052 & .257 & 2.141 & .036 \\
\hline
\end{tabular}

Dependent variable: available to pay for phone + PDA

Source: The authors.

TABLE 5 - Regression for phone with all features integrated, assessing for the available to pay factor with social behavior.

\begin{tabular}{|c|c|c|c|c|c|}
\hline \multirow{2}{*}{ Model (factors) } & \multicolumn{2}{|c|}{ Non-standard ratios } & \multirow{2}{*}{$\begin{array}{c}\text { Standard ratios } \\
\text { Beta }\end{array}$} & \multirow{2}{*}{$\mathbf{t}$} & \multirow{2}{*}{ Sig. (P) } \\
\hline & B & Standard error & & & \\
\hline Constant & -205.293 & 428.119 & & -0.480 & .633 \\
\hline Social factor (phone + TS) & 244.133 & 72.120 & .387 & 3.385 & .001 \\
\hline
\end{tabular}

Dependent variable: available to pay for phone + camera + mp3 + PDA $\mathrm{TS}=$ All products integrated (Camera, $\mathrm{mp} 3$ and $\mathrm{PDA})$

Source: The authors. 


\subsection{Study of preference based on price and brand as scenarios - Study 2}

\subsection{Method for Study 2}

\subsection{I.I Research design}

The second study intends to test hypotheses related to consumer preference on two conditions: well-known brand / unknown brand and high price / low price. In this study $2 \times 2$, respondents were randomly assigned to each of the four conditions and requested to rate the offered alternative. The study was applied to 115 Social Sciences College students in the North of Brazil, different from those requested in Study 1. Figure 3 shows the scenario proposed with expected interactions. Letter $U$ means the preferred use, symbols HP and UP inside the brackets mean hedonic and utilitarian preferences, respectively. Each block, i.e., each cell, (individual questionnaire) was applied to a different group of respondents.

In this study, we proposed low and high prices, defined by the previous results in Study 1 . The brand used was Nokia as the high brand and Mandarina as the low brand. We then confirmed the reputation for these brands defined. With these four different scenarios, preference should change, presenting interaction in this research and supporting hypotheses 3 and 4 .

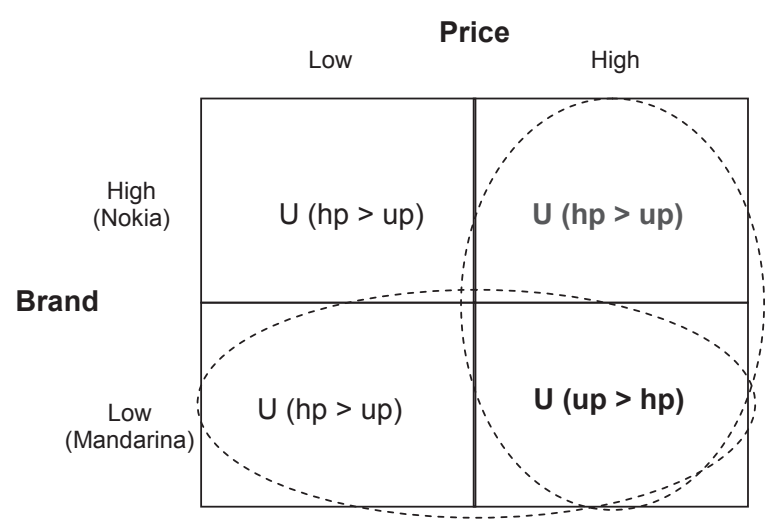

FIGURE 3 - Matrix of technological preference study, given the brand and price as stimulus environment.

Source: The authors.

\subsection{I.2 Stimulus}

In this second study, two different brands were presented to four different groups (scenarios) of respondents, wherein each group received a brand with a different price projected. Accordingly, the four scenarios described had two mobile phone models, one Nokia costing R\$ $1,000.00$ or $\mathrm{R} \$ 200.00$, and Mandarina costing $\mathrm{R} \$ 1,000.00$ or $\mathrm{R} \$ 200.00$. For each product, they were given the possibility to choose the mobile phone they wanted, based on different hedonism and utilitarianism features. Two degrees of choices were presented, one hedonic (phone with integrated mp3) and another one utilitarian (phone with electronic schedule to organize, send and receive appointments and messages).

\subsection{I.3 Dependent variable}

The dependent variable was the preference, based on high and low brands and high and low prices. Having set a $2 \times 2$ study, two factors were created to define the scenario and also different questionnaires for each part of the matrix. The difference in use of features should create the significance and interaction in the proposed study.

\subsection{I.4 Independent variables}

The same factors seen in Study 1 were measured in Study 2, with hedonism, utilitarianism, social behavior, risk and quality of the product assessed as independent variables. These factors were presented as fun, pleasure, need, usefulness, valued, user-friendliness, happiness, quality and perception of the risk with the purchase for integrated products. The scales to build this study were all taken from an article written by Okada (2005), on which we based the measurement and validation of the research on explanation, and a study conducted by Ajzen (1991), which presents scales for social value. The explanation and the type of use should support the choice made, by explaining the reason and the behavior for each preference in each scenario. With these factors, we intended to conduct 
a regression and variance analysis, assessing contents to find the way in which constructs were conducted.

\subsection{I.5 Procedure}

Separating the four scenarios mentioned above, each questionnaire contained a product presented with a brand and proposed price, plus the option to choose this mobile phone with a hedonic feature (mp3) or utilitarian feature (schedule). Other questions with a 7 Likert points scale were applied, assessing the usefulness, fun, quality and features of individual uses of the services existing in the mobile phone. Questionnaire results were analyzed on the SPSS software, and the same Study 1 standards were analyzed to define significance between decision factors.

\subsubsection{Study 2 results}

Following Figure 4, we analyzed regression, and presented significance for each component seen in Table 6. $\mathrm{R}^{2}$ for each regression presented in the table was $0.30,0.20$ and 0.24 , respectively, which validated the project. The difference in the model presented from Study 1 to Study 2 is found in the possibility of choice, and presented in accordance with the scenarios developed. In Study 2, preferences and use of utilitarian and hedonic attributes were included in the preference block, as respondents could choose according to the product type. After choosing one of the products presented with different features, the other subsequent block would measure the hedonic and utilitarian explanation, as well as the feelings supplementing, describing or explaining the choice, such as happiness, risk, reputation of the price, usefulness and quality. Therefore, the preference block creates a new proposition for the model. Table 7 presents the correlation between factors supporting the model and scenarios presented.

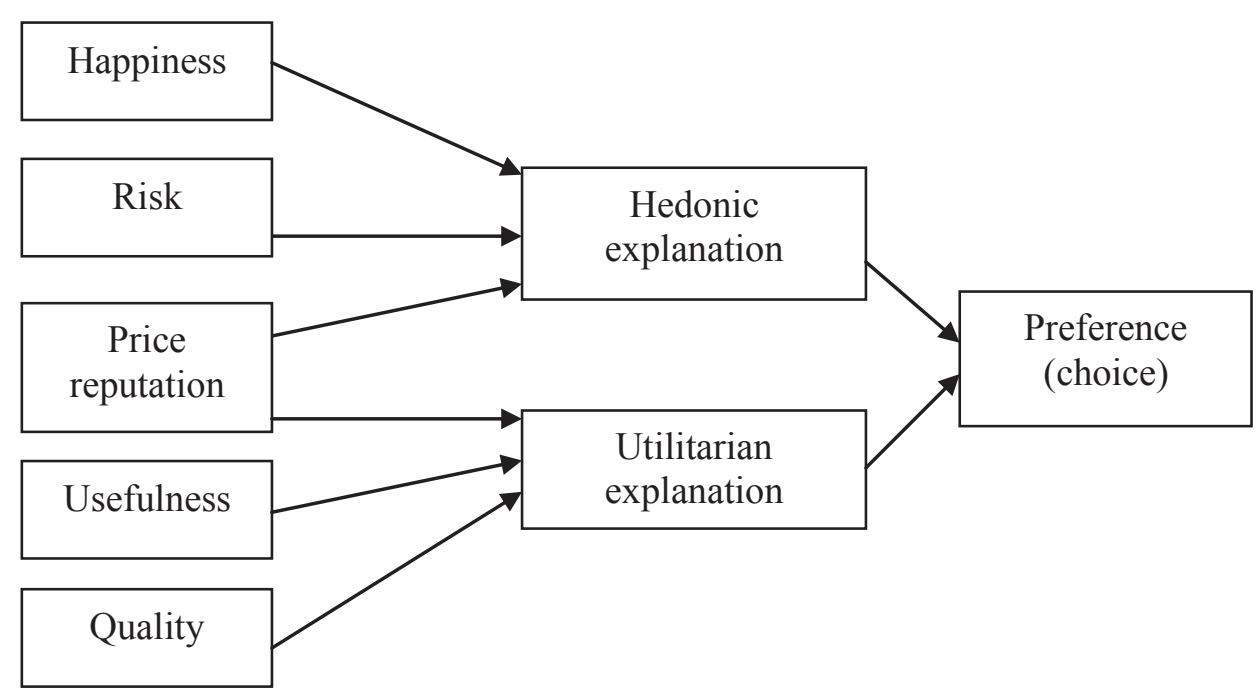

FIGURE 4 - Explanation and value model, directly influencing the preference study model.

Source: The authors. 
TABLE 6 - Regression analysis performed following brand and price scenario studies and utilitarian and hedonic explanation.

\begin{tabular}{|c|c|c|c|c|c|c|}
\hline \multirow{2}{*}{ Independent variable } & \multirow{2}{*}{$\begin{array}{c}\text { Dependent } \\
\text { variable }\end{array}$} & \multicolumn{2}{|c|}{ Non-standard ratios } & \multirow{2}{*}{$\frac{\text { Standard ratios }}{\text { Beta }}$} & \multirow{2}{*}{$\mathbf{t}$} & \multirow{2}{*}{ Sig. (P) } \\
\hline & & B & Standard error & & & \\
\hline Constant & & 1.676 & .157 & & 10.646 & .000 \\
\hline Utilitarian factor & \multirow[b]{2}{*}{ Preference } & -0.103 & .020 & -0.413 & -5.081 & .000 \\
\hline Hedonic factor & & .109 & .022 & .394 & 4.839 & .000 \\
\hline Constant & \multirow{4}{*}{ Hedonism } & 2.795 & .698 & & 4.004 & .000 \\
\hline Happiness factor & & .442 & .107 & .372 & 4.120 & .000 \\
\hline Price assessment factor & & -0.151 & .089 & -0.162 & -1.697 & .093 \\
\hline Risk factor & & .138 & .081 & .164 & 1.703 & .092 \\
\hline Constant & \multirow{4}{*}{ Utilitarianism } & -0.418 & 1.020 & & -.409 & .683 \\
\hline Usefulness factor & & .613 & .135 & .399 & 4.543 & .000 \\
\hline Price assessment factor & & .253 & .089 & .245 & 2.855 & .005 \\
\hline Quality factor & & .131 & .119 & .097 & 1.103 & .273 \\
\hline
\end{tabular}

Source: The authors.

The choice presents two different values, whereas Study 1 presented only a spot analysis - having been integrated to be measured, the current model does not create an assessment for the consumer's individual preference decision only, but also factors connected thereto.

Variance (Anova) and covariance (Ancova) analyses were conducted in study $2 \times 2$ to check interactions between brand and price factors, using preference as a co-factor to develop covariance. Even if Figure 5 shows preference interacting somehow differently between the scenarios, the statistical analysis shows low interaction results between most factors, using the abovementioned explanation as a dependent variable.

TABLE 7 - Table of correlation between explanation factors measured in Study 2.

\begin{tabular}{lcccccccc}
\hline Factors & Hed & Need & Use & Val & Friedly & Happi & Qual & Risk \\
\hline Hedonism (fun) & 1 & & & & & & & \\
Need (utilitarianism) & .055 & 1 & & & & & & \\
Usual & .189 & $.410^{* *}$ & 1 & & & & & \\
Valued & $.211^{*}$ & .174 & $.329^{* *}$ & 1 & & & \\
User friendly & .080 & -0.058 & .082 & .110 & 1 & & & \\
Happiness & $.380^{* *}$ & $.229^{*}$ & $.319^{* *}$ & $.352^{* *}$ & .109 & 1 & & \\
Quality & .105 & $.189^{*}$ & .222 & $.205^{*}$ & -0.015 & $.422^{* *}$ & 1 & \\
Risk & .169 & .096 & -0.021 & .052 & .175 & .170 & -0.041 & 1 \\
\hline
\end{tabular}

* Significant correlation at a 0.05 level.

** Significant correlation at a 0.01 level.

Source: The authors.

By conducting a variance analysis, we detected that when the brand was defined as the source, fun and quality as dependent variables, marginal significance and optimal significance of $p=0.081$ and $p=0.003$, respectively, were found When price was source, valued, user-friendliness, quality and risk were used as dependent variables, optimal and reasonable significances of $\mathrm{p}=0.007$, 
0.069, 0.062 and 0.019, respectively, were found. In the brand-price interaction, significances were assessed only with variables user-friendliness and risk, with marginal significance values of 0.091 and 0.081 .

Accordingly, Figure 5 strongly supports hypothesis 3, and moderately supports hypothesis 4 , in which abovementioned variances are explained by the figure of averages, by demonstrating factors that lead to changes in decision, leaving them more inferring in nature, given the user friendliness and risk involved, i.e., an unknown brand has become more difficult to use because of lack of previous experience, and riskier given its reputation, thereby generating a change in preference.

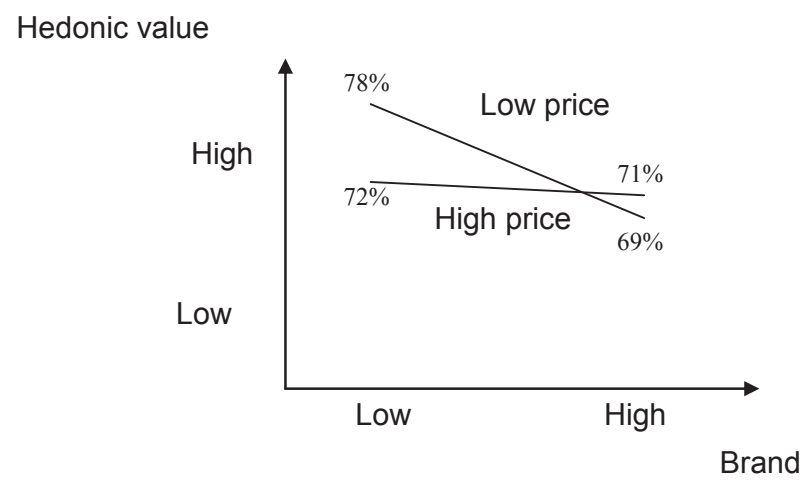

FIGURE 5 - Preference measured in questionnaires, connecting brand and price to hedonism values.

Source: The authors.

As Figure 5 should have the high price line supposedly increased (growing), from low to high brand, which did not happen, the study at least supports the analysis that this price was not reduced in percentage, going below the hedonism level: it remained virtually constant. We supposed that the low price line had a high hedonism value, which happened even with a little reduction presented. Accordingly, we observed that the lower value - low price with high brand - remained above the border between hedonism low and high levels.

\subsection{Preference study based on budget and choice as environments - Study 3}

\subsection{Method for Study 3}

\subsection{I.I Research design}

Study 3 intends to test hypotheses related to consumer preference on two conditions: one receiving the product as a gift or buying it for themselves, and 2) having a budget (limit) in the purchase scenario or not having this budget without knowing that different scenarios exist. In this other $2 \times 2$ study, respondents were randomly assigned to each of the four conditions (without knowing that the others scenario possibilities existed) and requested to choose a product among the options ranging in the benefits offered. The scenarios were designed as in the previous study, with two possibilities: one hedonic and the other utilitarian. Figure 6 shows the study proposed with the interactions expected for the research. Letter $\mathrm{U}$, as in the previous study, means preference of use, whereas HP and UP, hedonic and utilitarian preferences, respectively. This study was applied to 123 Engineering college students in the North of Brazil, different from those respondents in Studies 1 and 2 above.

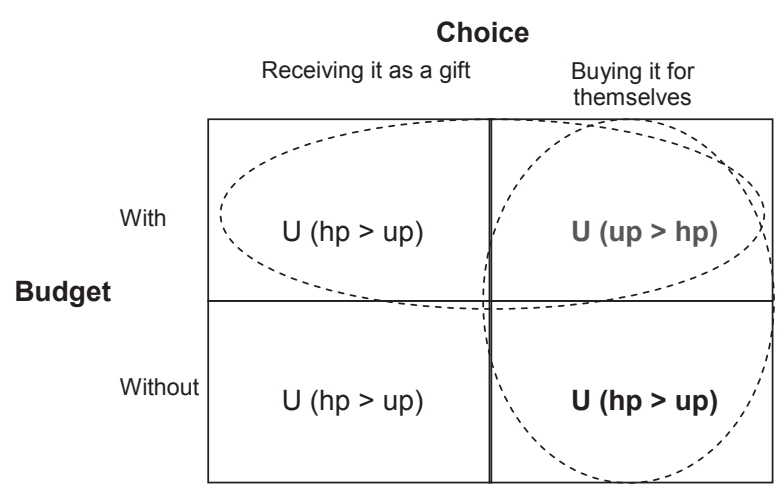

FIGURE 6 - Matrix of the study on technological preference, budget data and choice as environments.

Source: The authors. 
As in Study 2, we also prepared four questionnaires with two choice degrees. The stimuli were triggered based on the scenario of having or not budget, and buying the chosen product to themselves or receiving it as a gift, as well as two possible choices: a phone with mp3 costing $\mathrm{R} \$ 600.00$, or a phone with an electronic schedule costing $\mathrm{R} \$ 400.00$. In both scenarios, the budget proposed was $\mathrm{R} \$ 400.00$, so as to validate hypotheses 5 and 6 , as, if the consumer was willing to spend more than their budget, it would have to be a hedonic product costing more than the utilitarian product and the budget set.

\subsection{I.3 Dependent variable}

The dependent variable was preference, based on the scenarios of having (with) or not (without) limited budget, and buying the product or receiving it as a gift. Having set a $2 \times 2$ study, these two factors lead to an environment in which change of preference due to benefits perceived by the consumers is possible. The different possibilities of feature use should create significance and interaction in the study proposed, based on the intention to use or by the product.

\subsection{I.4 Independent variables}

The same factors seen in Studies 1 and 2 were measured, with the following independent variables: hedonism, utilitarianism, social value, risk perception with purchase and quality of the product assessed. These factors are the same ones presented above: fun, pleasure, need, usefulness, valued, user-friendliness, happiness, quality and risk perception. The explanation and the type of use should support the choice made, by explaining the reason and the behavior for each scenario chosen. Accordingly, a regression and variance analyses were performed for all contents, in order to check which way constructs would follow.

\subsection{I.5 Procedure}

Separating the four scenarios described in the research proposed, each questionnaire contained a product with or without budget, in addition to the type of choice proposed, plus the composition of the type of device to be picked for its hedonic or utilitarian features. As in Study 2 , the questionnaires on the scenario were the same, with changes in the environment proposed for the research only. Data was worked on SPSS, significances were analyzed, and expected connections were studied, considering the choices and perceptions of values by consumers.

\subsubsection{Study 3 results}

Following the same model in Study 2 seen in Figure 4 -, we analyzed regression, and presented significance for each component seen in Table 8. $\mathrm{R}^{2}$ for each regression presented in the table was $0.45,0.20$ and 0.30 , respectively. We detected that significance existed for the intention to use related to hedonic and utilitarian factors, but significance for utilitarianism and hedonism as dependent variables were not fully supported by preceding variables.

In different scenarios, based on the identification of budget and choice, the same factors were presented with different features for each item. Therefore, the study analyzed the intentions in each preference proposed and their explanations in questions subsequently answered. Table 9 presents the correlation of these factors, stating the reason for little significance for hedonism and utilitarianism as dependent variables.

Variance and covariance studies were conducted for this research, assessing the $2 \times 2$ design and looking for interactions between factors, budget and choice. When analyzing Figure 7 , we detect that preferences presented in a set have some interactions when assessed individually, based on changes in scenario; however, the statistical analysis shows little interaction between factors measured and explanations such as dependent variables. 
TABLE 8 - Regression analysis performed following budget and choice scenario studies and utilitarian and hedonic explanation.

\begin{tabular}{|c|c|c|c|c|c|c|}
\hline \multirow{2}{*}{ Independent variable } & \multirow{2}{*}{$\begin{array}{l}\text { Dependent } \\
\text { variable }\end{array}$} & \multicolumn{2}{|c|}{ Non-standard ratios } & \multirow{2}{*}{$\frac{\text { Standard ratios }}{\text { Beta }}$} & \multirow{2}{*}{$\mathbf{t}$} & \multirow{2}{*}{ Sig. $(P)$} \\
\hline & & B & Standard error & & & \\
\hline Constant & \multirow[b]{3}{*}{ Preference } & 1.650 & .184 & & 8.977 & .000 \\
\hline Utilitarian factor & & -0.123 & .023 & -0.403 & -5.332 & .000 \\
\hline Hedonic factor & & .128 & .022 & .444 & 5.866 & .000 \\
\hline Constant & \multirow{4}{*}{ Utilitarianism } & .837 & .955 & & .877 & .383 \\
\hline Usefulness factor & & .825 & .125 & .558 & 6.624 & .000 \\
\hline Price reputation factor & & -0.029 & .103 & -0.023 & -0.281 & .780 \\
\hline Quality factor & & -0.062 & .101 & -0.052 & -0.620 & .537 \\
\hline Constant & \multirow{4}{*}{ Hedonism } & 2.565 & .975 & & 2.631 & .010 \\
\hline Happiness factor & & .318 & .121 & .251 & 2.619 & .010 \\
\hline Price reputation factor & & .035 & .130 & .026 & .268 & .789 \\
\hline Risk factor & & .118 & .091 & .128 & 1.302 & .196 \\
\hline
\end{tabular}

Source: The authors.

TABLE 9 - Table of correlation between explanation factors measured in Study 3.

\begin{tabular}{lcccccccc}
\hline Factors & Hed & Need & Use & Val & Friedly & Happi & Qual & Risk \\
\hline Hedonism (fun) & 1 & & & & & & & \\
Need (utilitarianism) & -0.186 & 1 & & & & & \\
Usual & -0.070 & $.546^{*}$ & 1 & & & & \\
Valued & .116 & .178 & $.326^{* *}$ & 1 & & & \\
User friendly & -0.157 & .184 & $.341^{* *}$ & .018 & 1 & & \\
Happiness & $.264^{* *}$ & .082 & $.343^{* *}$ & $.392^{* *}$ & .024 & 1 & & \\
Quality & $.323^{* *}$ & .061 & $.207^{*}$ & .176 & .036 & $.303^{* *}$ & 1 & \\
Risk & .166 & -.041 & -0.062 & $.254^{* *}$ & -0.189 & .125 & $.250^{* *}$ & 1 \\
\hline
\end{tabular}

* Significant correlation at a 0.05 level.

** Significant correlation at a 0.01 level.

Source: The authors.

For the choice as a study source, there was no significance in any explanation used as dependent variables. For the budget as source and need as dependent variable, significance in the variance analysis was optimal, with $\mathrm{p}=$ 0.043, which means that budget is limited to the purchase - decision for something utilitarian. As regards interaction between budget and choice, no significance was detected.
Figure 7 and utilitarianism variance support hypotheses 5 and 6, which show that a change in scenario influences the choice in which budget is an element, and that consumers are available to spend more than their budget, as integrated products offer the desired hedonic value. When the analysis has no budget limit, preference is for hedonic products. 


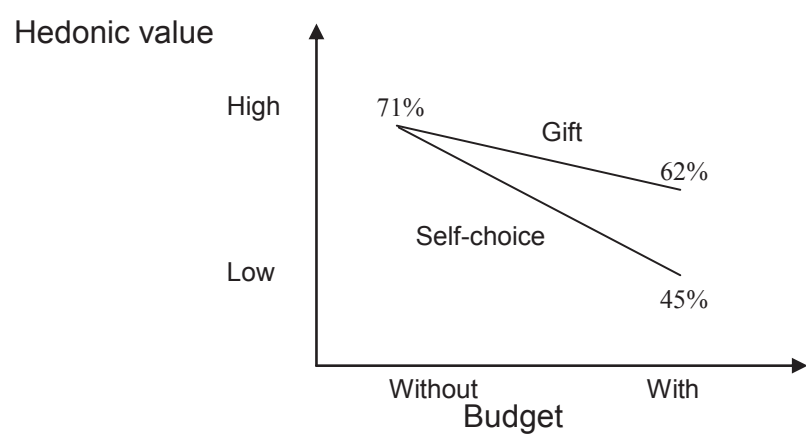

FIGURE 7 - Preference measured in questionnaires, by relating budget and choice to hedonic value.

Source: The authors.

Reassessing the research proposed, scenarios with budgets were designed with the budget amount lower than the price of the hedonic device, which moderately supports hypothesis 5 . In the case of self-choice - one buying the product for themselves - vs. budget, hypothesis 6 was supported, as there is a decrease in choice - Figure 7, in which utilitarianism is preferred over hedonism for the products bought. Furthermore, variance analysis with excellent inferred need shows that the utilitarian value is not connected to the "receiving as a gift" scenario. In analyzing the "receiving as a gift," utilitarian influence is lower, as, although budget describes a utilitarian factor, the hedonic value is higher given its little connection with the guilt related to gifts (Figure 7).

In analyzing the "receiving as a gift" behavior and self-choice, still in Figure 7, and with inferring variance for the budget and need, the study graphically shows the hedonic value, reducing it to the scenario in which it has a budget, which explains the usefulness variance analysis. The difference in this reduction between the "receiving as a gift" and "self-choice" scenarios exists as a low reduction, more when the product is received as a gift than when it is purchased.

\section{DISCUSSION AND CONCLUSION}

This article introduces three different studies conducted using quantitative and preference research, and demonstrates the use and boundary factors for telecommunications products, particularly mobile phones and integrations thereof. Integrations like mp3 player, digital camera, PDA etc. are responsible for changes in consumer preferences, based on different scenarios created, involving price, brand, self-choice and budget limits.

The importance of this paper lies in its building specific scenarios, in detail, for the development of experiments, thus validating the research design to identify consumption behavior, which consumers are usually uncomfortable explaining. As an experiment, this paper shows that consumers change their buying intentions, as well as values, when the scenario changes. It identifies the importance of integrated features and the parameters of the environment proposed by the specific designs in Figures 3 and 6. For the marketing literature, this validates preceding studies on the hedonism and utilitarianism theories, by showing that consumers make their choices based on pleasure, but explain them based on guilt of the hedonic consumption or expensive consumption.

Study 1 shows a comparison between basic mobile phones and dedicated products, such as an mp3 player, digital camera and PDA, and mobile phones integrated with these features separately, in addition to an all-in-one device. In this study, we can assess the use and preference, based on hedonism and utilitarianism, that provide results to develop further studies, and can be considered a reference for technological preference, which has been more deeply analyzed in Studies 2 and 3.

Study 2 shows how consumers prefer their devices, based on the four different scenarios involving high and low prices and high and low brands. This part of the research tends to encourage consumers differently in each cell scenario for different preferences and decisions. Encouraging results were found with hedonic value in preference and utilitarian explanation in such intended acquisition, based on the feeling of guilt for the hedonic value involved.

Study 3 , also a $2 \times 2$ study involving different scenarios, used the existence and non-existence of a budget limit, in addition to 
"one buying the product for themselves" and "receiving it as a gift" as factors to design the research conducted. As in the preceding study, consumers are expected to change their choices, based on different scenarios, in order for us to verify the hypotheses presented. Regular results were found in this study, but we believe that part of the problem is related to the existence of two choices in a single scenario cell.

As one of the intents of the paper was to measure consumers' preference, by analyzing that they are expected to change their choices, based on different scenarios, hypotheses 3 to 6 analyzed the studies of scenarios proposed. Therefore, in order to ensure a better result, we propose the development of these studies for new products other than those presented herein, and the expansion of the model for a $2 \times 2 \times 2$ study, thus creating eight different scenarios and eight different response groups. Accordingly, only one product would be included by scenario in order to ensure better variance analysis. This new proposal is very interesting for this technological field, and we believe it will be very productive for future research, as it may lead to an understanding of consumers' behavior given the use and preference for each type of technology, and considering the complexity of the best cost-effectiveness relationship.

From this perspective, according to existing literature, the article failed to prove all significances for all factors presented. However, they were interrelated and this could be solved with changes in scenario or studies for a cube model - three dimensions - in lieu of the square matrix used. Accordingly, the technology field has still many study and development possibilities to assess the market, with perception of values for innovation and choices for high technologies.

Against this background, this article concludes new value perceptions for technological products such as mobile phones, identifies, for companies operating in this field, which features best describe consumers' preferences, and therefore proposes which attributes should be more focused when designing new products for the current market.

\section{REFERENCES}

AJZEN, I. The theory of planned behavior. Organizational Behavior and Human Decision Process, San Diego, v. 50, v. 2, p. 179-211, Dec. 1991.

BRUCKS, M.; ZEITHALM, V. A.; NAYLOR, G. Price and brand name as indicators of quality dimensions for consumer durables. Academy of Marketing Science, Thousand Oaks, v. 28, n. 3, p. 359-374, June 2000.

BRUNNER, F. M. A psychological rendering of consumerism. 1996. 208 f. Thesis (Ph.D.) Pacifica Graduate Institute, Santa Barbara, 1996.

COWLEY, E.; MITCHELL, A. A. The moderating effect of product knowledge on the learning and organization of product information. Journal of Consumer Research, Chicago, v. 30, n. 3, p. 443-454, Dec. 2003.

DAHL, D. W.; HONEA, H.; MANCHANDA, R. V. Three rs of interpersonal consumer guilt: relationship, reciprocity, reparation. Journal of Consumer Psychology, Mahwah, v. 15, n. 4, p. 307-315, 2005.

DANAHER, P. J.; HARDIE, B. G. S.; PUTSIS JUNIOR., W. P. Marketing-mix variables and the diffusion of successive generations of a technological innovation. Journal of Marketing Research, Chicago, v. 38, n. 4, p. 501-514, Nov. 2001.

FUNK, J. L. Key technological trajectories and the expansion of mobile Internet applications. The Journal of Policy, Regulation and Strategy for Telecommunications, Information and Media, [S. 1.], v. 6, n. 3, p. 208-215, 2004.

HAN, J. K., CHUNG, S. W.; SOHN, Y. S. Technology convergence: when do consumers prefer converged products to dedicated products? Journal of Marketing, Chicabo, v. 73, n. 4, p. 97-108, July 2009. 
HARRIS, J.; BLAIR, E. A. Functional compatibility risk and consumer preference for product bundles. Journal of the Academy of Marketing Science, Thousand Oaks, v. 34, n. 1, p. 19-26, Dec. 2006.

HEATH, C.; SOLL, J. B. Mental budgeting and consumer decisions. Journal of Consumer Research, Chicago, v. 23, n. 1, p. 40-52, June 1996.

$\mathrm{HOCH}, \mathrm{S}$. Product experience is seductive. Journal of Consume Research, Chicago, v. 29, n. 3, p. 448-454, Dec. 2002.

JOKELA, T. When good things happen to bad products: where are the benefits of usability in the consumer appliance market? Interaction, New York, v. 11, n. 6, Dec. 2004.

KATZ, J. E.; SUGIYAMA, S. Mobile phones as fashion statements: evidence from student surveys in the US and Japan. New Media and Society, London, v. 8, n. 2, p. 321-337, Apr. 2006.

KIM, Y.; LEE, J.-D.; KOH, D. Effects of consumer preferences on the convergence of mobile telecommunications devices. Applied Economics, London, v. 37, n. 7, p. 817-826, 2005.

LIU, C.-M. The Effects of Promotion on Brand Decision in the Cellular Telephone Industry. The Journal of Product and Brand Management, [S.l.], v.11, n.1, 2002.

MUKHERJEE, A.; HOYER, W. D. The effect of novel attributes on product evaluation. Journal of Consumer Research, Chicago, v. 28, n. 3, p. 462-472, Dec. 2001.

NEELAMEGHAM, R.; CHINTAGUNTA, P. K. Modeling and forecasting the sales of technology products. Quantitative Marketing and Economics, Norwell, v. 2, n. 3, p. 195-232, Sept. 2004
NOWLIS, S. M.; MANDEL, N.; MCCABE, D. B. The effect of a delay between choice and consumption on consumption enjoyment. Journal of Consumer Research, Chicago, v. 31, n. 3, p. 502-510, Dec. 2004.

NUNES, J. C. A cognitive model of people's usage estimation. Journal of Marketing Research, Chicago, v. 37, n. 4, p. 397-409, Nov. 2000.

NUNES, P.; WILSON, D.; KAMBIL A. The all-inone market. Harvard Business Review, Boston, v. 78, n. 3, p. 19-20, May/June 2000.

OKADA, E. M. Justification effects on consumer choice of hedonic and utilitarian goods. Journal of Marketing Research, Chicago, v. 42, n. 1, p. 43-53, Feb. 2005.

SIMONSON, I.; NOWLIS, S.; LEMON, K. The effect of local considerations sets on global choice between lower price and higher quality. Marketing Science, Linthicum, v. 12, n. 4, p. 357-377, Fall 1993.

SNOJ, B.; KORDA, A. P., MUMEL, D. The relationships among perceived quality, perceived risk and perceived product value. The Journal of Product and Brand Management, Bradford, v. 13, n. 3, p. 156-167, 2004.

TAYLOR, L.; TITMUSS R.; LEBRE, C. The challenges of seamless handover in future mobile multimedia networks. IEEE Personal Communications, [S.1.], v. 6, n. 2, p. 32-37, Apr. 1999.

VRDOLJAK, M; VRDOLJAK, S. I.; SKUGOR, G. Fixed-mobile convergence strategy: technologies and market opportunities. IEEE Communications Magazine, [S.1.], v. 38, n. 2, p. 116-121, Feb. 2000. 